\title{
Extending Miscanthus Cultivation with Novel Germplasm at Six Contrasting Sites
}

\author{
Olena Kalinina ${ }^{1 *}$, Christopher Nunn ${ }^{2}$, Ruth Sanderson ${ }^{2}$, Astley F. S. Hastings ${ }^{3}$, \\ Tim van der Weijde ${ }^{4}$, Mensure Özgüven ${ }^{5}$, Ivan Tarakanov ${ }^{6}$, Heinrich Schüle ${ }^{7}$, \\ Luisa M. Trindade ${ }^{4}$, Oene Dolstra ${ }^{4}$, Kai-Uwe Schwarz ${ }^{8}$, Yasir lqbal ${ }^{1}$, Andreas Kiesel ${ }^{1}$, \\ Michal Mos ${ }^{9}$, Iris Lewandowski ${ }^{1}$ and John C. Clifton-Brown ${ }^{2}$ \\ ${ }^{1}$ Department of Biobased Products and Energy Crops, Institute of Crop Science, University of Hohenheim, Stuttgart, \\ Germany, ${ }^{2}$ Institute of Biological, Environmental and Rural Sciences, Aberystwyth University, Aberystwyth, UK, ${ }^{3}$ The Institute \\ of Biological and Environmental Sciences, University of Aberdeen, Aberdeen, UK, ${ }^{4}$ Department of Plant Breeding, \\ Wageningen University, Wageningen, Netherlands, ${ }^{5}$ Faculty of Agriculture and Natural Sciences, Konya Food and Agriculture \\ University, Konya, Turkey, ${ }^{6}$ Department of Plant Physiology, Russian State Agrarian University - Moscow Timiryazev \\ Agricultural Academy, Moscow, Russia, ${ }^{7}$ German Agrarian Centre, Potash, Ukraine, ${ }^{8}$ Schwarz, Braunschweig, Germany, \\ ${ }^{9}$ Blankney Estates, Blankney, UK
}

Miscanthus is a genus of perennial rhizomatous grasses with C4 photosynthesis which is indigenous in a wide geographic range of Asian climates. The sterile clone, Miscanthus $\times$ giganteus (M. $\times$ giganteus), is a naturally occurring interspecific hybrid that has been used commercially in Europe for biomass production for over a decade. Although, M. $\times$ giganteus has many outstanding performance characteristics including high yields and low nutrient offtakes, commercial expansion is limited by cloning rates, slow establishment to a mature yield, frost, and drought resistance. In this paper, we evaluate the performance of 13 novel germplasm types alongside $M . \times$ giganteus and horticultural "Goliath" in trials in six sites (in Germany, Russia, The Netherlands, Turkey, UK, and Ukraine). Mean annual yields across all the sites and genotypes increased from $2.3 \pm 0.2$ $\mathrm{t}$ dry matter ha ${ }^{-1}$ following the first year of growth, to $7.3 \pm 0.3,9.5 \pm 0.3$, and 10.5 $\pm 0.2 \mathrm{t}$ dry matter ha ${ }^{-1}$ following the second, third, and fourth years, respectively. The highest average annual yields across locations and four growth seasons were observed for $M . \times$ giganteus $\left(9.9 \pm 0.7 \mathrm{t}\right.$ dry matter ha $\left.{ }^{-1}\right)$ and interspecies hybrid OPM-6 (9.4 $\pm 0.6 \mathrm{t}$ dry matter $\left.\mathrm{ha}^{-1}\right)$. The best of the new hybrid genotypes yielded similarly to M. $\times$ giganteus at most of the locations. Significant effects of the year of growth, location, species, genotype, and interplay between these factors have been observed demonstrating strong genotype $\times$ environment interactions. The highest yields were recorded in Ukraine. Time needed for the crop establishment varied depending on climate: in colder climates such as Russia the crop has not achieved its peak yield by the fourth year, whereas in the hot climate of Turkey and under irrigation the yields were already high in the first growing season. We have identified several alternatives to M. $\times$ giganteus which have provided stable yields across wide climatic ranges, mostly interspecies hybrids, and also Miscanthus genotypes providing high biomass yields at specific geographic locations. Seed-propagated interspecific and intraspecific hybrids, with high stable yields and cheaper reliable scalable establishment remain a key strategic objective for breeders.

\footnotetext{
Keywords: Miscanthus, novel hybrids, multi-location field trials, establishment, productivity, marginal land
} 


\section{INTRODUCTION}

There is an increasing demand for sustainably produced biomass in the growing European bioeconomy but its material and energetic use should not compete with food supply (Lewandowski et al., 2016). Therefore, the additionally required biomass should not be grown on good agricultural land but on land that is economically or bio-physically marginal for food production. According to Allen et al. (2014), there are an estimated 1,350,000 hectares (ha) of such land in Europe that is abandoned from or unsuitable for food crop production and could be preferentially exploited for growing biomass crops.

Miscanthus is a genus of high-yielding perennial rhizomatous grasses with $\mathrm{C} 4$ photosynthesis. It is considered a promising candidate bioeconomy crop due to the combination of high yields, low input demand, good environmental performance, multiple biomass use options, and the potential to grow on land that is considered marginal for food production (Dohleman and Long, 2009; McCalmont et al., 2015; Lewandowski et al., 2016). Miscanthus demonstrates a broad genetic variability in the area of its origin, namely East-Asia (Clifton-Brown et al., 2016). However, this theoretical potential cannot yet be exploited fully in Europe. Currently the industrial use of this crop in Europe is limited to one standard clone Miscanthus $\times$ giganteus $(M . \times$ giganteus; Hodkinson and Renvoize, 2001), a sterile interspecific hybrid propagated vegetatively. Cultivation and yields of $M . \times$ giganteus can be limited by low temperatures in the northern European regions (Clifton-Brown and Lewandowski, 2000) and drought in the southern regions (Hastings et al., 2009a,b). Another limitation to the broader distribution of miscanthus are the high production costs for $M . \times$ giganteus (Lewandowski et al., 2016). Vegetative propagation is an expensive way of establishing the plantations (Xue et al., 2015). Introducing new germplasm from the wild collections is needed to extend the geographical range in which Miscanthus can be cultivated and overcome some of the current limitations, and some early selections from European breeding programs should create invaluable knowledge of the "Genotype $\times$ Environment" interactions.

Germplasm used in European breeding programs belong mainly to the species M. sacchariflorus and M. sinensis. To date, their interspecific hybrids, such as $M . \times$ giganteus, are generally higher yielding than the pure species (Davey et al., 2017) in temperate zones. A cold tolerance test with five genotypes showed that certain $M$. sinensis types could withstand lower winter temperatures than $M . \times$ giganteus and $M$. sacchariflorus (Clifton-Brown et al., 2000). In general, M. sinensis interspecific hybrids have thinner and shorter stems than M. sacchariflorus and their hybrids, which combined lead to lower yields in trials with the scientific standard planting density of 20,000 plants ha ${ }^{-1}$ (Iqbal and Lewandowski, 2014). In the UK and Germany, the miscanthus breeding program led by Aberystwyth over the past decade has focussed on producing interspecific $M$. sinensis $\times$ M. sacchariflorus hybrids with high yield, cold or other stress tolerance and seed production (Clifton-Brown et al., 2016). As high seed production in interspecific hybrids does not occur naturally in Northern Europe, breeders in the Netherlands have focussed on the genetic improvement of intraspecific hybrids of $M$. sinensis types. Scientific field trials have shown the potential for other $M$. sinensis intraspecies hybrids in drought prone areas (Clifton-Brown et al., 2002). During the past decade, the breadth of Miscanthus germplasm available in Europe has been expanded through plant collection trips (Clifton-Brown J. C. et al., 2011; Clifton-Brown J. et al., 2011; Hodkinson et al., 2016). There is tremendous diversity available within the Miscanthus genus to exploit, particularly within $M$. sinensis which occurs in the widest climatic range of all Miscanthus species. M. sinensis types are known to senesce earlier than many tall $M$. sacchariflorus types (Robson et al., 2012). M. sinensis generally flowers in North European climates (Jensen et al., 2011), while most M. sacchariflorus needs warmer climates to flower before winter (Jensen et al., 2013). Although flowering in the production area potentially increases the invasive risk, this can be mitigated by the manipulation of ploidy to produce sterile triploids (Anderson et al., 2006).

In this paper, we report on a multi-location field plot experiment, where we have tested a range of selected diverse germplasm from the different Miscanthus species on a wide climatic gradient spanning Atlantic, continental, and Mediterranean climates. All the germplasm entries for this experiment were selected from breeding nurseries in Northern Europe. Four wild "tall M. sacchariflorus" types were selected in Aberystwyth from spaced plants trials planted from the accessions collected in 2006/7 from Eastern Asia. Four M. sinensis populations were selected: two from Wageningen University and two from open-pollinated "strong" M. sinensis parents selected in Northern Germany. Five interspecies hybrids of $M$. sinensis and $M$. sacchariflorus were selected in a spaced plant breeding nursery in Braunschweig, Germany from progeny of different crosses in 2011.

The overarching objective of this study was to create the understanding needed to extend the range for Miscanthus production in Eurasia. We were particularly interested in understanding if Miscanthus selected in UK, Netherlands, and Germany could both establish, over-winter and produce an economically viable yield with relatively low temperatures and rainfall in Eastern areas. There is a known opportunity for miscanthus cultivation in Eastern European countries such as Ukraine and Russia where both significant amounts of underused land and a strong local market for the biomass for heat exist. Our expectation was that best performers in terms of yield could be identified in each of the six sites due to environmental specificity: both at level of the germplasm groups and at the level of specific genotypes or populations. It was expected that the performance of some of the novel interspecies and intraspecies hybrids would match or exceed $M . \times$ giganteus, thus providing potential growers and end users with new options. We also believed that the knowledge generated by a multi-location trial approach, containing a wide selection of "relevant" germplasm types, would identify environmental specificity for both the parents and progeny of $M$. sinensis and $M$. sacchariflorus. This G $\times$ E information can be used to assist breeders to develop better 
future hybrids. For the purposes of examining $\mathrm{G} \times \mathrm{E}$ interactions we felt it is was necessary to reduce the number of variables by using a high proportion of clonal selections (genotypes) for 11 of the 15 selections rather than individuals from populations derived from "seed." If any of these clones proved outstanding, then breeding of seed propagated equivalents would be the logical next step. The four seeded entries (of $M$. sinensis type) would be used to explore if phenotypic variation within a population cross was a significant issue for the future expansion of a crop based on seeded M. sinensis hybrids.

Our first hypothesis was that, under the wide range of climate and soil conditions between Stuttgart (Germany), Moscow (Russia), Wageningen (The Netherlands), Adana (Turkey), Aberystwyth (UK), and Potash (Ukraine), significant differences would exist in establishment rate and yield performance of the novel germplasm types. The abiotic stress tolerance traits observed would be used to inform further breeding of future seeded hybrids.

Our second hypothesis was that new selections, heretofore only tested in spaced plant nurseries, could perform as well or better than $M . \times$ giganteus in competitive plot trials in sites with more extreme climates and poorer soils than have been tested to date.

\section{MATERIALS AND METHODS}

\section{Plant Material}

Germplasm to evaluate was selected by the breeders at Aberystwyth and Wageningen Universities. The fifteen selections included four genotypes of wild M. sacchariflorus, five interspecies hybrids of $M$. sacchariflorus $\times M$. sinensis, four M. sinensis seed-based population hybrids (two of which were paired crosses, and two open-pollinated) and two triploid standard clones: $M . \times$ giganteus (between $M$. sinensis and M. sacchariflorus; Greef and Deuter, 1993) and M. sinensis "Goliath" (M. sinensis $\times$ sinensis; Table 1$)$. The origins of the germplasm types or their parents, where known, ranged from 23 to $45 \mathrm{~N}$ (Supplementary Table 1). The wild M. sacchariflorus type collection sites ranged from 31 to $37 \mathrm{~N}$. Growing season rainfall (April-September) at the known locations of germplasm collection range from 500 to $2000 \mathrm{~mm}$ p.a. The mean minimum monthly winter temperatures in these areas ranged from -16 to $12^{\circ} \mathrm{C}$. The hybrids OPM-6, 7, 8, and 10 and the M. sinensis OPM-11, 12 and 15 were provided by Aberystwyth University and the M. sinensis genotypes OPM-13 and 14 were provided by Wageningen University. All hybrids and $M$. sinensis were diploid. Some of the wild M. sacchariflorus genotypes were tetraploid (see Supplementary Table 1).

In vitro propagation was used to produce "plug" plants in modular trays (Quick Pot $9638 \times 38 \times 78 \mathrm{~mm}$, HerkuPlast, Kubern, GmbH, Ering/Inn, Germany) from clones OPM 1-11. Seeded entries (OPM-12-15) were sown in similar trays. OPM13 and OPM-14 were raised in the Netherlands. OPM-12 and OPM-15 were raised in the UK. All were grown in the glasshouse before hardening off, transportation to and transplantation at the six field trial locations. Hereafter, all the germplasm types are referred to as "genotypes."
TABLE 1 | Germplasm selected for the multi-location trials.

\begin{tabular}{|c|c|c|c|}
\hline $\begin{array}{l}\text { Genotype } \\
\text { ID }\end{array}$ & Species & Accession details & $\begin{array}{l}\text { Propagation } \\
\text { method }\end{array}$ \\
\hline OPM-1 & $\mathrm{Sac}$ & Wild Sac & In vitro \\
\hline OPM-2 & Sac & Wild Sac & In vitro \\
\hline OPM-3 & Sac & Wild Sac & In vitro \\
\hline OPM-4 & Sac & Wild Sac & In vitro \\
\hline OPM-5 & Hybrid & $\begin{array}{l}\text { Wild } \operatorname{Sin} \times \text { Wild } \\
\text { Sac hybrid }\end{array}$ & In vitro \\
\hline OPM-6 & Hybrid & Wild Sac $\times$ Wild Sin & In vitro \\
\hline OPM-7 & Hybrid & Wild Sac $\times$ Wild Sin & In vitro \\
\hline OPM-8 & Hybrid & Wild Sac $\times$ Wild Sin & In vitro \\
\hline OPM-9 & Hybrid (Gig) & Wild Sac $\times$ Wild Sin & In vitro \\
\hline OPM-10 & Hybrid & Wild Sac $\times$ Wild Sin & In vitro \\
\hline OPM-11 & Sin (Goliath) & Wild $\operatorname{Sin} \times$ open & In vitro \\
\hline OPM-12 & $\operatorname{Sin}$ & Wild $\operatorname{Sin} \times$ open & Seeds \\
\hline OPM-13 & $\operatorname{Sin}$ & $\operatorname{Sin} \times \operatorname{Sin}$ & Seeds \\
\hline OPM-14 & $\operatorname{Sin}$ & $\operatorname{Sin} \times \operatorname{Sin}$ & Seeds \\
\hline OPM-15 & $\begin{array}{l}\text { Sac } \times \text { Sin } \times \text { open Sin } \\
\text { (open-pollinated hybrid with } \\
\text { dominating Sin phenotype } \\
\text { and high morphological } \\
\text { variability) }\end{array}$ & $\begin{array}{l}(\operatorname{Sac} \times \operatorname{Sin}) \times \text { open } \\
\operatorname{Sin}\end{array}$ & Seeds \\
\hline
\end{tabular}

Sac, M. sacchariflorus; Sin, M. sinensis; Hybrid, M. sinensis $\times$ M. sacchariflorus hybrid. Common clone names added where these exist [e.g., Gig = M. $\times$ giganteus, Sin (Goliath) $=M$. sinensis Goliath].

\section{Field Trials}

Between April and May 2012, 15 genotypes (Table 1) were established at six field locations (Figure 1) covering a wide range of environmental conditions (Supplementary Table 2): in Turkey near Adana, in Germany near Stuttgart, in Ukraine near Potash, in the Netherlands at Wageningen, in the United Kingdom near Aberystwyth and in Russia near Moscow. For the remainder of this paper, the sites are referred to by the name of the nearest town.

The field trials were established on arable or horticultural land except in Aberystwyth, where the trial was planted on marginal (low quality) grassland (Supplementary Table 2). At each site soil preparations suitable for the planting of cereals were made, removing the previous crop/vegetation and associated weeds. At each location the trial was planted as a randomized complete block design comprising three replicate blocks each containing a single plot of each of the 15 genotypes. Each plot measured 5 $\times 5 \mathrm{~m}$ and contained 49 plants in a $7 \times 7$ grid with a planting density of 1.96 plants $\mathrm{m}^{-2}$. The total trial area at each site was 75 $\times 43 \mathrm{~m}$.

In 2012, soil samples were taken before planting and fertilization from two randomly selected plots in each replicate block at each location. Soil samples were collected at the $0-30$, $30-60,60-90 \mathrm{~cm}$ layers where there was sufficient profile depth. Samples were analyzed for $\mathrm{pH}$, plant available nitrogen $\left(\mathrm{N}_{\min }\right)$ and total potassium $(\mathrm{K})$, phosphorous $(\mathrm{P})$, and magnesium (Mg) (Supplementary Table 3). The plant available nitrogen 


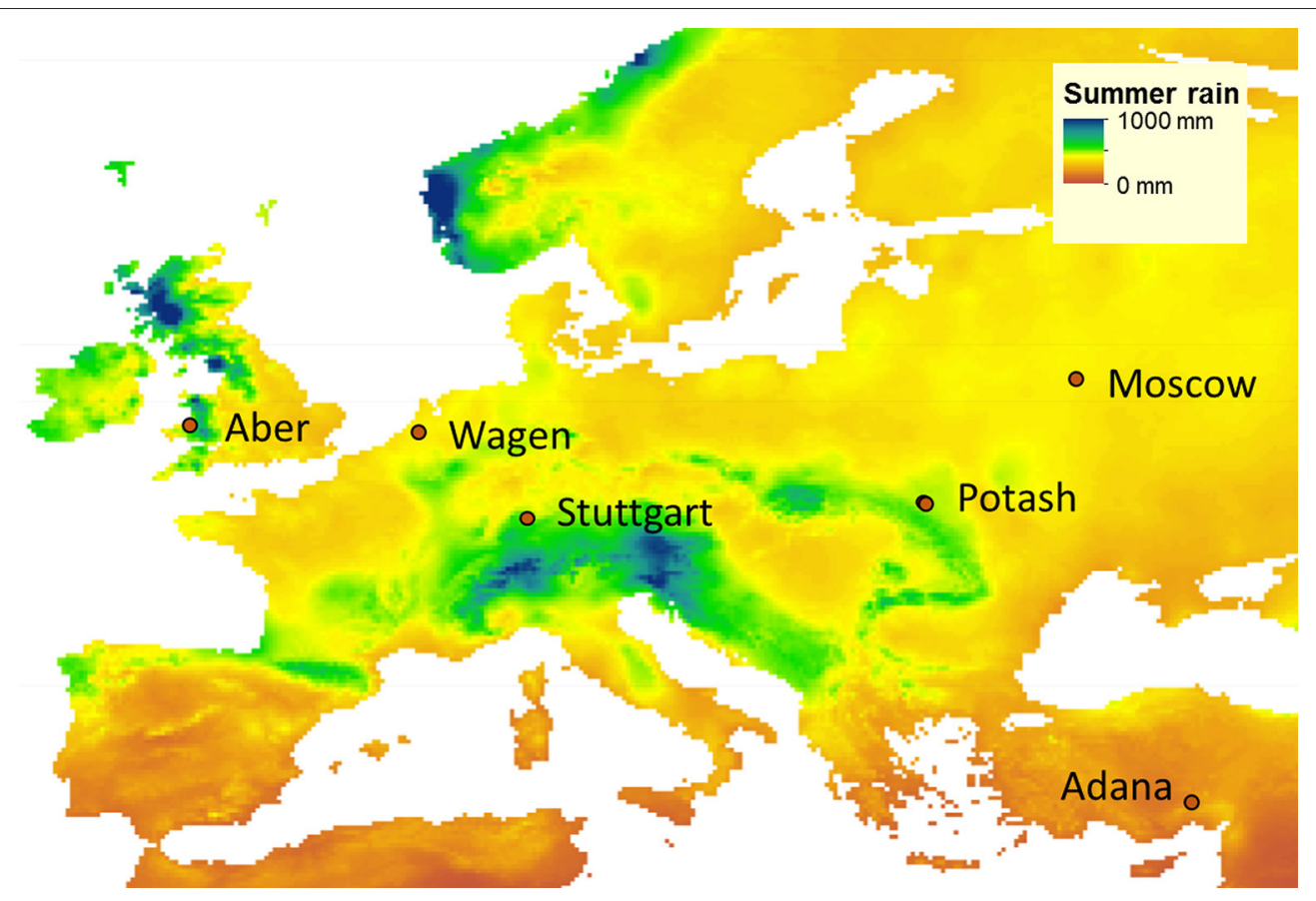

FIGURE 1 | Location of the field trials established in May 2012: Aberystwyth (Aber; United Kingdom), Wageningen (Wagen; The Netherlands), Stuttgart (Germany), Adana (Turkey), Potash (Ukraine), and Moscow (Russia), and historical summer rainfall map (average of equinox to equinox rainfall from 2010 to 2014 from CRU TS v. 3.24).

was determined by using $\mathrm{CaCl}_{2}$ extraction followed by FIA measurement (DIN ISO 14255:1998-11). Determination of soil $\mathrm{P}$ and $\mathrm{K}$ was carried out by using CAL extraction followed by flame photometer or FIA measurement (OENORM L 1087:201212-01). Soil pH was determined by using a glass electrode after $\mathrm{CaCl}_{2}$ extraction (DIN ISO 10390:2005; Ehmann et al., 2017). Further inter-row soil cores were taken from each plot in October 2012 using a soil column cylinder auger (Eijelkamp, Giesbeek, Netherlands) to determine soil bulk density, soil depth, and stone content (Supplementary Table 3).

\section{Trial Management and Climatic Conditions}

Miscanthus plugs were planted by hand in May 2012 except in Adana where the trial was established earlier, in mid-April, to avoid dry and hot weather whilst planting. In spring 2012, fertilizer was applied at all the sites at rates 44 and $110 \mathrm{~kg} \mathrm{ha}^{-1}$ year $^{-1} \mathrm{P}$ and $\mathrm{K}$, respectively, which, combined with residual soil nutrients, designed to match crop requirements (Lewandowski et al., 2000). No nitrogen fertilizer was applied in the first year to minimize weed growth. From year 2 fertilizer was applied at the rate of $140 \mathrm{~kg} \mathrm{ha}^{-1} \mathrm{~K}, 100 \mathrm{~kg} \mathrm{ha}^{-1} \mathrm{P}$, and $60 \mathrm{~kg} \mathrm{ha}^{-1} \mathrm{~N}$ applied once per season in spring, rates designed to ensure non-limiting crop nutrition at all sites.

From 2013, continuous drip irrigation was applied in Adana to compensate for lack of rainfall and to maintain the trial during prolonged drought periods. Irrigation was applied more often and in larger volumes in 2013 to ensure crop establishment and then reduced in 2014 and 2015 to identify genotypes suited to arid and hot climatic conditions. Volumes of water applied were recorded. Emerging weeds were removed regularly by hand during the growing seasons 2012-2014 at all sites.

Climate data (rainfall, air, and soil temperature and radiation) were obtained from the weather stations at the study sites. Supplementary Table 4 summarizes climatic conditions during each growing season at each location and the irrigation applied in Adana.

\section{Measurements}

Plant survival was recorded in May 2013 as the number of plants producing new shoots in spring. Plant loss was calculated as the number of non-shooting plants expressed as a percentage of the total plants planted per plot. Any gaps occurring due to overwinter mortality in the first winter were filled in using plants from the adjacent replacement plots planted for this purpose at each corresponding site in 2012.

At the end of the third growing season (autumn 2014) canopy height was measured and stem number per plant (only stems reaching at least $60 \%$ of canopy height) was recorded on 3-5 central plants per plot.

Each year biomass was harvested from the core square ( 9 plants; middle $2 \mathrm{~m}^{2}$ ) of the plots in February-April depending upon location and when the crop was dry. Cutting height for yield determination was $5 \mathrm{~cm}$ above the soil surface. Harvested plant material was dried to constant weight at $60^{\circ} \mathrm{C}$. Dry matter yield was calculated as tons of dry matter (DM) ha ${ }^{-1}$. Total DM yield was calculated as the sum of the plot yields over four growing seasons. 


\section{Statistical Analyses}

All statistical analyses were performed with the aid of GenStat (Version 18.2; VSN International Ltd., Hemel Hempstead, UK; Payne et al., 2015). Within location, effects of species group on total 4-year biomass yield were assessed by analysis of variance according to the randomized block design. Yields of OPM-510 in seasons 3 and 4 were compared by analysis of variance as split plot in time. Effects of genotype and location and their interaction on biomass yield, plot mean values for canopy height and stem count in year 3 were assessed by residual maximum likelihood analysis and using a separate residual variance at each location. Where necessary, multiple pairwise comparisons within tables of means were accounted for by Bonferroni-adjustment of the comparison-wise type I error rate. Sensitivity of biomass yield, canopy height, and stem count of the genotypes to the six environments was assessed by modified joint regression analysis (Finlay and Wilkinson, 1963) as implemented in the RFINLAYWILKINSON procedure of GenStat (Payne et al., 2015). Stem counts were transformed to the square root scale prior to calculating plot means and prior to each analysis.

\section{RESULTS}

\section{Plant Overwinter Survival}

At most field sites, there were few plant losses in the first winter after planting (Table 2). However, in Aberystwyth the plants did not establish well in the first year and in total $43 \%$ of the plants needed to be replaced. A possible reason for high plantlet mortality at this location may have been the weather conditions viz. cool air temperatures in 2012 and flooding at the time of miscanthus planting. Aberystwyth had the highest (727 mm, which is double the long term average) total rainfall and the lowest mean air temperature $\left(11^{\circ} \mathrm{C}\right.$, which is $2^{\circ}$ lower than the long term average) among the sites in the first growing season (Supplementary Table 4). This location also had the lowest $\mathrm{DD}_{\text {(base10) }}$ and PAR among the field trial sites in 2012 (see Supplementary Table 5), two important parameters known to influence miscanthus growth and yields (Clifton-Brown et al., 2000), which could result in weaker and smaller plants by winter.

At the other locations, on average only $3 \%$ of all plants needed to be replaced after winter. The highest losses were observed with OPM-15 (a seed-propagated, Sac $\times$ Sin $\times$ Sin open-pollinated hybrid) where on average $10 \%$ of plants needed to be replaced (Aberystwyth site not included). The seedlings of this accession were initially slightly smaller at planting due to a slightly later sowing date than the other genotypes, which may have contributed to the higher mortality rate observed.

At the more northern sites with continental climate, Moscow and Potash, higher plant mortality was observed than in Wageningen or Stuttgart. At the two former locations some losses were observed for most of the genotypes but losses never exceeded $14 \%$ for any of the genotypes concerned. Interestingly, M. $\times$ giganteus showed no plant losses at the warmer field locations in Adana, Stuttgart, and Wageningen, but higher losses than the new $M$. sinensis $\times$ M. sacchariflorus hybrids at colder locations in Potash and Moscow, where the lowest minimum air and soil surface temperatures were recorded (Supplementary Table 6). In Adana, significant plant losses were only observed for some of the $M$. sinensis accessions (OPM-11, 12, 13, and 15).

\section{Biomass Yield}

\section{Annual Biomass Yield}

Annual biomass ( $\mathrm{t} \mathrm{DM} \mathrm{ha}^{-1}$ ) yield varied depending on the growing season, trial location, and Miscanthus genotype. Overall, biomass yields increased with increasing crop maturity. Mean annual yields across all the sites and genotypes increased from 2.3 $\pm 0.2 \mathrm{t} \mathrm{DM} \mathrm{ha}^{-1}$ from the first year of growth, to $7.3 \pm 0.3,9.5 \pm$ 0.3 , and $10.5 \pm 0.2 \mathrm{t} \mathrm{DM} \mathrm{ha}^{-1}$ from the second, third, and fourth years, respectively. The highest yielding location was Potash with the average annual yield of $9.6 \pm 0.4 \mathrm{t} \mathrm{DM} \mathrm{ha}^{-1}$. The lowestyielding was Aberystwyth with $4.0 \pm 0.3 \mathrm{t} \mathrm{DM} \mathrm{ha}^{-1}$ of average annual yield. The highest average yields across locations and years were observed for $M . \times$ giganteus $\left(9.9 \pm 0.7 \mathrm{tDM} \mathrm{ha}^{-1}\right)$ and interspecies hybrid OPM-6 (9.4 $\left.\pm 0.6 \mathrm{t} \mathrm{DM} \mathrm{ha}^{-1}\right)$. Interspecific hybrids on average produced higher yields than $M$. sinensis and $M$. sacchariflorus genotypes ( $p<0.001$ for the comparison of $M$. sinensis and $M$. sacchariflorus groups with hybrids).

At all sites except Adana annual biomass yield increased throughout the first 3 years while the crop was establishing (Figure 2). However, in Adana, high biomass yields were achieved in the first growing season. At this location, the average first-year yield reached $8.1 \pm 0.4 \mathrm{t} \mathrm{DM} \mathrm{ha}^{-1}, 7.7$ times higher than

TABLE 2 | Plant losses (\% of plants planted) recorded in the field during the first winter (November 2012 until March 2013 ) for the 15 Miscanthus genotypes at six field locations.

\begin{tabular}{|c|c|c|c|c|c|c|c|c|c|c|c|c|c|c|c|}
\hline \multirow[t]{3}{*}{ Location } & \multicolumn{15}{|c|}{ Genotype (OPM) and species group } \\
\hline & \multicolumn{4}{|c|}{ Sac } & \multicolumn{6}{|c|}{ Sac $\times$ Sin } & \multicolumn{5}{|c|}{ Sin } \\
\hline & 1 & 2 & 3 & 4 & 5 & 6 & 7 & 8 & 9 Gig & 10 & 11 & 12 & 13 & 14 & 15 \\
\hline Adana & 0 & 0 & 0 & 2 & 1 & 0 & 1 & 1 & 0 & 1 & 34 & 16 & 12 & 0 & 18 \\
\hline Stuttgart & 4 & 1 & 0 & 3 & 2 & 2 & 0 & 1 & 0 & 0 & 0 & 3 & 2 & 3 & 4 \\
\hline Potash & 3 & 3 & 1 & 2 & 0 & 3 & 2 & 1 & 13 & 2 & 1 & 8 & 1 & 4 & 14 \\
\hline Wageningen & 1 & 0 & 1 & 0 & 2 & 0 & 0 & 0 & 0 & 1 & 0 & 0 & 0 & 0 & 1 \\
\hline Aberystwyth & 59 & 82 & 45 & 55 & 44 & 28 & 29 & 27 & 32 & 35 & 35 & 31 & 50 & 57 & 39 \\
\hline Moscow & 3 & 13 & 0 & 5 & 0 & 1 & 6 & 1 & 11 & 5 & 7 & 13 & 4 & 4 & 11 \\
\hline
\end{tabular}



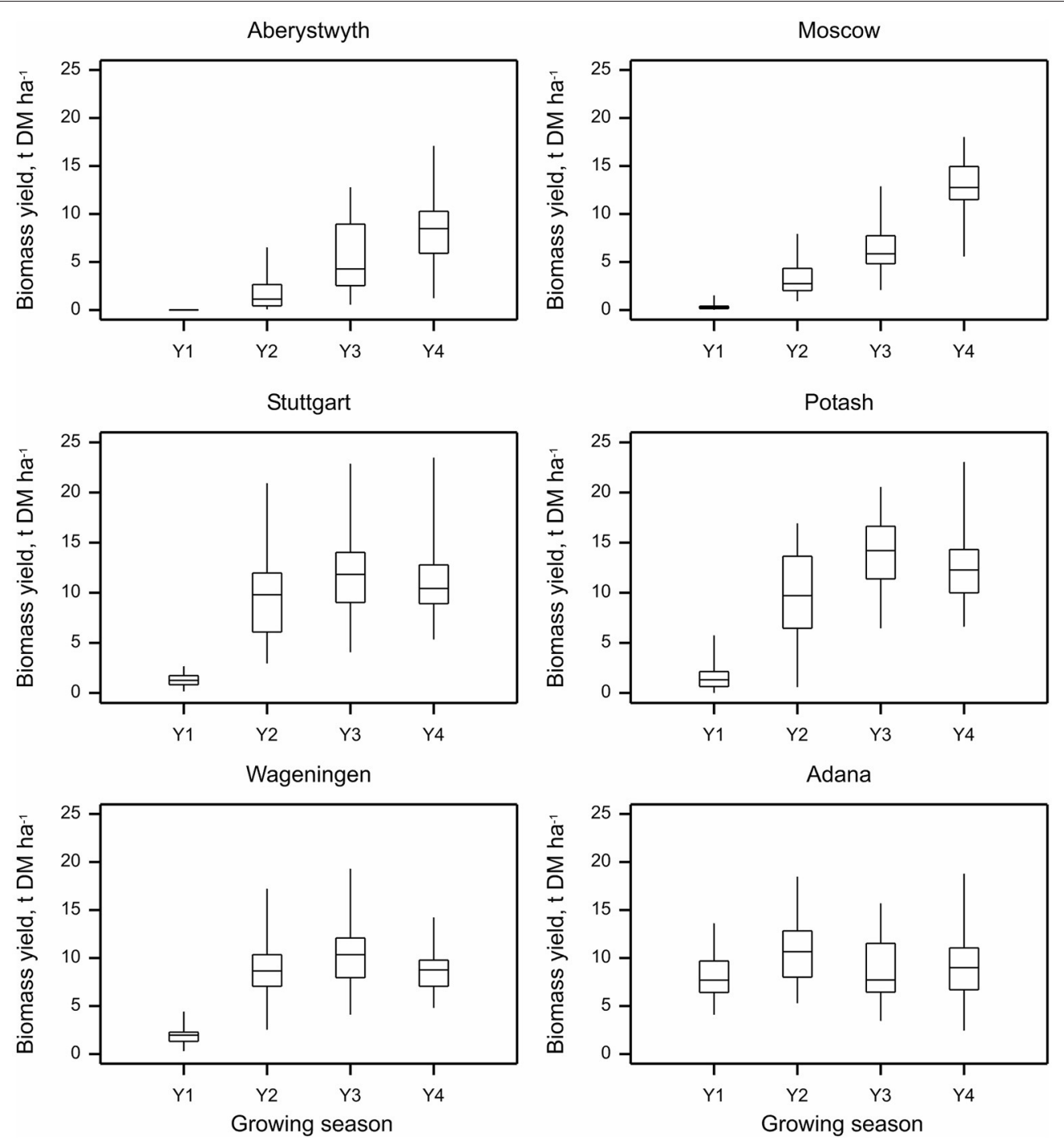

FIGURE 2 | Annual biomass yield of Miscanthus (15 genotypes pooled) at six trial locations over four growing seasons 2012-2015 (Y1-Y4). Whiskers denote the overall range at each location within each year, boxes denote interquartile ranges and within this the horizontal bar denotes the median.

at the other sites. It increased further to $10.7 \pm 0.4 \mathrm{t} \mathrm{DM} \mathrm{ha}^{-1}$ in the second growing season and although dropping slightly in the following growing season remained relatively stable throughout seasons 3 and $4\left(8.7 \pm 0.5\right.$ and $9.4 \pm 0.5 \mathrm{t} \mathrm{DM} \mathrm{ha}^{-1}$ in 2014 and 2015, respectively). Interestingly, at Moscow and Aberystwyth, locations where the crop apparently took longer to establish, the yields steadily increased throughout the 4 years and possibly had not achieved their peak by year 4 . At Stuttgart and Potash, good yields were achieved in the second year $(9.5 \pm 0.6$ and $9.5 \pm 0.7 \mathrm{t} \mathrm{DM} \mathrm{ha}^{-1}$, respectively), there was however high within-site variation at these locations (Figure 2). At Stuttgart, highly variable soil depth within the site $(40-100 \mathrm{~cm})$ could be responsible for this variation in yield. At Wageningen and Potash, biomass yield was generally lower in year 4 than year $3(14.1 \pm 0.5$ $v 12.6 \pm 0.5$ at Potash, and $10.4 \pm 0.4 v 8.7 \pm 0.3 \mathrm{t} \mathrm{DM} \mathrm{ha}^{-1}$ at Wageningen in 2014 and 2015, respectively), which was possibly due to lower rainfall in 2015 (in particular at Potash, rainfall in 2015 was almost half that in 2014; Supplementary Table 4).

In terms of biomass yield, genotypes ranked differently by year and by location. The higher-yielding genotypes were different at the six sites (see also yield ranking in Lewandowski et al., 2016). The best-yielding genotype across locations from the first growing season was $M . \times$ giganteus (OPM-9) producing on average $3.4 \pm 1.0 \mathrm{t} \mathrm{DM} \mathrm{ha}^{-1}$ and after the second and third seasons, the sac $\times \sin$ hybrid OPM-6 with $10.6 \pm 1$ and $12.4 \pm$ $0.9 \mathrm{t} \mathrm{DM} \mathrm{ha}^{-1}$, respectively. In the fourth growing season, $M . \times$ giganteus showed again the highest average yield of $13.8 \pm 0.7 \mathrm{t}$ $\mathrm{DM} \mathrm{ha}^{-1}$ across locations. Overall these two genotypes were the highest biomass producers showing either the first or the second best yield depending on the year (Table 3).

At Adana, $M . \times$ giganteus was the highest-yielding genotype in the first three seasons whilst in 2015, the best yield was 
TABLE 3 | Annual biomass yield (t DM ha-1) of 15 Miscanthus genotypes at six trial locations in 2014 (Y3) analyzed by REML using separate residual variances for each location.

\begin{tabular}{|c|c|c|c|c|c|c|c|c|c|c|c|c|c|c|c|c|}
\hline \multirow[t]{2}{*}{ Location } & \multicolumn{16}{|c|}{ Genotype (OPM) } \\
\hline & 1 & 2 & 3 & 4 & 5 & 6 & 7 & 8 & 9 & 10 & 11 & 12 & 13 & 14 & 15 & Mean \\
\hline Aberystwyth & 1.5 & 2.9 & 6.4 & 3.3 & 5.6 & 10.6 & 4.7 & 11.3 & 8.3 & 10.8 & 3.0 & 2.9 & 3.0 & 2.2 & 4.8 & 5.4 \\
\hline Moscow & 3.4 & 5.5 & 4.7 & 2.9 & 7.2 & 10.4 & 6.8 & 7.6 & 7.8 & 8.5 & 6.2 & 6.0 & 5.6 & 5.7 & 4.3 & 6.2 \\
\hline Stuttgart & 8.3 & 12.9 & 14.6 & 6.1 & 13.7 & 16.3 & 12.7 & 14.2 & 13.6 & 13.6 & 11.8 & 12.5 & 10.2 & 9.5 & 7.9 & 11.9 \\
\hline Potash & 14.1 & 18.0 & 15.4 & 13.3 & 17.3 & 17.0 & 14.3 & 13.3 & 16.7 & 15.7 & 15.3 & 10.5 & 9.2 & 11.7 & 10.3 & 14.1 \\
\hline Wageningen & 5.9 & 10.3 & 9.8 & 8.3 & 9.4 & 10.8 & 9.5 & 14.5 & 14.3 & 12.1 & 12.8 & 9.8 & 9.3 & 9.1 & 9.5 & 10.4 \\
\hline Adana & 6.3 & 6.3 & 5.2 & 4.5 & 7.3 & 9.4 & 7.0 & 7.3 & 13.0 & 6.8 & 12.4 & 12.5 & 12.1 & 9.8 & 10.4 & 8.7 \\
\hline Mean & 6.6 & 9.3 & 9.4 & 6.4 & 10.1 & 12.4 & 9.2 & 11.4 & 12.3 & 11.3 & 10.2 & 9.0 & 8.2 & 8.0 & 7.9 & \\
\hline
\end{tabular}

Statistical significance of effects of genotype $p<0.001$ (average s.e. 0.61), location $p<0.001$ (average s.e. 0.59) and interaction $p<0.001$ (average s.e. 1.45).

recorded for M. sinensis OPM-12. At Aberystwyth, hybrid OPM8 consistently yielded the highest of all the genotypes in the first three seasons but in year 4 it was outperformed by $M . \times$ giganteus although not significantly so. At the other locations the best-yielding genotypes varied depending on the year (see also Lewandowski et al., 2016).

\section{Total Biomass Yield over Four Growing Seasons}

The highest total biomass yield of $37.9 \pm 1.8 \mathrm{t} \mathrm{DM} \mathrm{ha}^{-1}$ (location mean for all genotypes) was observed at Potash, Ukraine and the second highest in Adana, Turkey $\left(36.9 \pm 1.3 \mathrm{t} \mathrm{DM} \mathrm{ha}^{-1}\right)$. The lowest-yielding locations were Aberystwyth with a total yield of $15.4 \pm 1.3 \mathrm{t} \mathrm{DM} \mathrm{ha}^{-1}$ and Moscow with $22.5 \pm 0.9 \mathrm{t} \mathrm{DM} \mathrm{ha}^{-1}$.

Significant differences $(p<0.01)$ between the species groups (i.e., between "M. sacchariflorus," "M. sinensis," "Hybrids," and "M. × giganteus control clone") in total four year yield were observed at each location (Figure 3). The total yield of the new interspecies hybrids did not differ $(p>0.05)$ from that of $M . \times$ giganteus at all the locations, except Adana (the only location with additional irrigation applied), where $M$. $\times$ giganteus outperformed hybrids $(p<0.05)$. In particular, the hybrids OPM-6, 8, 10 achieved the same 4-year yield as $M . \times$ giganteus (locations pooled), but also one of the $M$. sacchariflorus types, OPM-2, had total yield similar to that of M. $\times$ giganteus clone. However, there was still evidence of significant differences between genotypes within species group at Aberystwyth $(p<0.021)$, Stuttgart $(p<0.023)$, and Potash $(p<$ $0.01)$.

The $M$. sinensis types on average produced significantly less biomass than interspecies hybrids, except in Adana, where $M$. sinensis types OPM-11 and 12 produced the highest yields, and Wageningen where these two groups yielded similarly. $M$. sinensis types had on average similar total yields to $M$. sacchariflorus genotypes at all trial locations, except in Potash where $M$. sacchariflorus genotypes produced a higher total yield than $M$. sinensis types $(p<0.05$; Figure 3$)$. M. sacchariflorus on average (four genotypes pooled) produced similar to $M . \times$ giganteus yields at Potash and Stuttgart and had lower total yields than $M$. giganteus at the other locations. Over a period of 4 years, OPM-2 (M. sacchariflorus) and hybrid genotypes OPM-6,
8, and 10 showed similar total yields to $M . \times$ giganteus (locations pooled).

Total biomass DM yield over 4 years was linearly correlated ( $p$ $<0.001$ ) with the annual yields achieved in each of the growing seasons. Over all locations the correlation increased from 0.49 in the year $1-0.90$ in the second, 0.86 in the third growing seasons and 0.62 in the year 4 .

\section{Genotype Differences in Yield in an Established Crop (2014-2015)}

Figure 4 shows the yields of the individual interspecies hybrid genotypes and $M . \times$ giganteus in years 3 and 4 , when the crop reached or approached maturity and yields stabilized. In these growing seasons there was no genotype effect on annual yield at any location except Adana, i.e., biomass yields for $M . \times$ giganteus and $\operatorname{Sac} \times \operatorname{Sin}$ hybrids were similar $(p>0.05)$. At Adana, $M . \times$ giganteus showed higher biomass yield than OPM-7, 8, and $10(p$ $<0.05$ ) while OPM-5 and 6 produced biomass yields comparable to $M$. $\times$ giganteus. At Potash and Wageningen year 3 biomass yields were greater than in year $4(p<0.001)$, which reflect differences in the weather conditions (specifically significantly decreased summer rainfall in 2015) between the years at these sites (Supplementary Table 4). At Moscow and Aberystwyth, overall mean biomass yield was affected by year $(p<0.001$ and $p$ $=0.002$, respectively) and increased from year 3 to 4 indicating further crop maturation at these sites. However, at Aberystwyth the effect of year was not consistent across all genotypes with only $M . \times$ giganteus showing a significant yield increase $(p<0.05)$ between years 3 and 4 . All other genotypes showed similar yield in years 3 and 4 . In Stuttgart, there were no effects $(p>0.05)$ of genotype, year or of an interaction between the two.

\section{Canopy Height and Stem Number}

Canopy height in autumn (Table 4) was affected by site, genotype and their interaction $(p<0.001)$. On average, the tallest plants were observed in Stuttgart, Potash, and Wageningen (mean canopy height $198.5 \pm 7.7,194.4 \pm 6.5$, and $191.7 \pm 5.0 \mathrm{~cm}$, respectively) and the shortest were in Moscow $(122.1 \pm 3.1 \mathrm{~cm})$. The genotypes of $M$. sacchariflorus, OPM-1 and 3 in particular, and $M . \times$ giganteus (OPM-9) had the highest canopy heights 

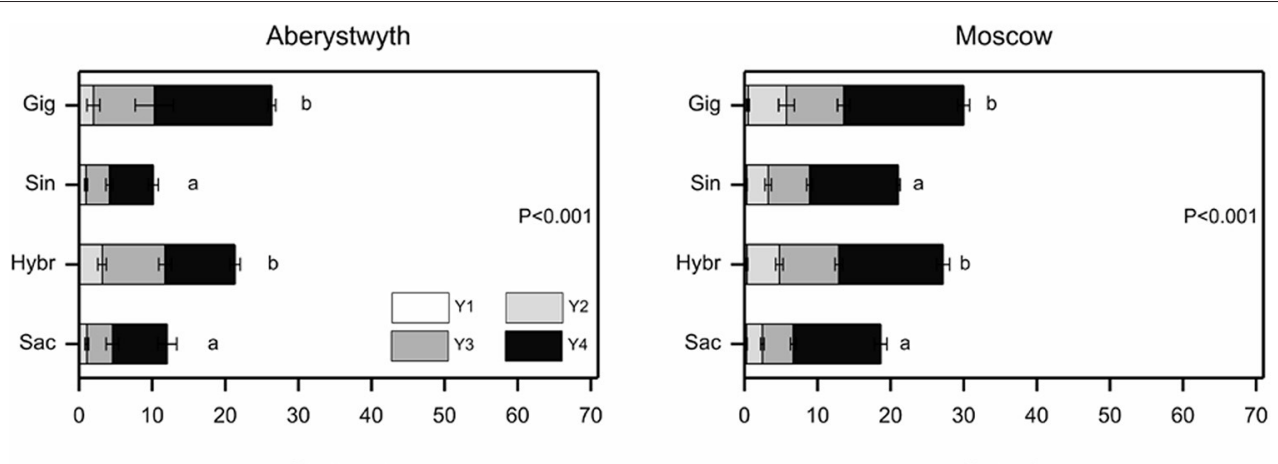

Stuttgart

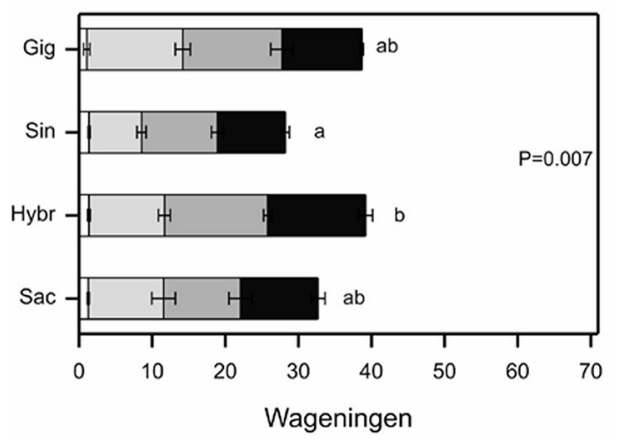

Potash
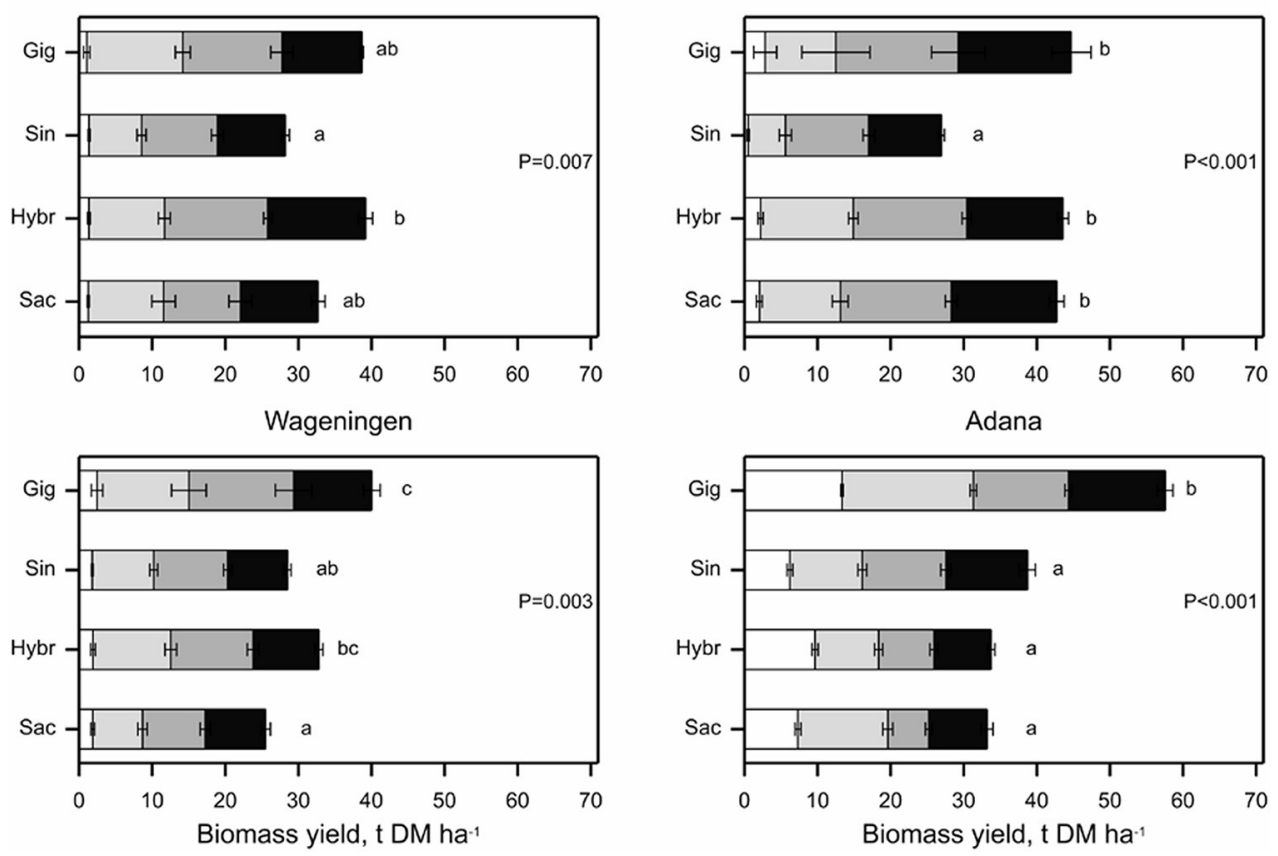

FIGURE 3 | Cumulative biomass yield over four growing seasons (Y1-Y4) at six trial locations. Miscanthus genotypes were categorized as: Gig = Miscanthus $\times$ giganteus, $\operatorname{Sin}=M$. sinensis, Hybr $=M$. sinensis $\times M$. sacchariflorus hybrids or Sac $=M$. sacchariflorus genotypes. Error bars represent \pm standard error of the mean for corresponding growing season. Probabilities indicate the overall effect of species group on total cumulative biomass yield within each site and differing letters indicate species group means differ $(p<0.05)$ based on bonferroni adjusted multiple comparisons.

among all the genotypes $(204.1 \pm 15.6,194.2 \pm 14.8$, and $212.8 \pm$ $11.1 \mathrm{~cm}$, respectively).

Stem number in growing season 3 (Table 5) was also significantly affected by site and genotype with an interaction $(p<0.001)$. Highest average stem number was observed at Wageningen (60.5 stems plant $^{-1}$ ) and the lowest at Aberystwyth (27.8 stems plant ${ }^{-1}$ ). Across locations, the highest average stem number was observed for the hybrid genotypes OPM-6, 7, and 10, with 74.1, 71.2, and 68.7 stems plant $^{-1}$, respectively. The lowest average stem numbers were observed in $M . \times$ giganteus (OPM9; 29.1 stems plant $\left.^{-1}\right)$ and OPM-2, 1, 12, and 11 (33.6, 35.1, 35.5, and 37.3 stems plant ${ }^{-1}$, respectively). M. sacchariflorus genotypes tended to have lower stem numbers than $M$. sinensis types.

There was also a site $\times$ genotype interaction observed for stem number $(p<0.001)$. Based on analysis of variance within each location, genotypes differed in stem number at the field sites in Moscow, Potash, Stuttgart, and Wageningen $(p=0.01, p=$ $0.001, p<0.001$, and $p<0.001$, respectively). At Wageningen and Moscow, OPM-6 had the highest stem numbers among the genotypes tested (Table 5). At Stuttgart, OPM-6 and 7 were the genotypes with the highest stem numbers. At Potash, stem number was highest in OPM-7. OPM-6, a high-yielding genotype, showed a higher $(p<0.05)$ number of stems compared to $M . \times$ giganteus at three locations: in Stuttgart, Wageningen, and Moscow. At two sites, Aberystwyth and Adana, no significant differences ( $p=0.517$ and $p=0.877$, respectively) in stem number between genotypes were detected.

In the combined data set over all locations there was a positive linear correlation between biomass yield $\left(\mathrm{t} \mathrm{DM} \mathrm{ha}{ }^{-1}\right)$ and both autumn canopy height $(\mathrm{cm})$ and stem number (stems plant ${ }^{-1}$ ) in the third growing season (2014). Canopy height was more strongly associated (Pearson $r=0.55, p<0.001$ ) with yield than 

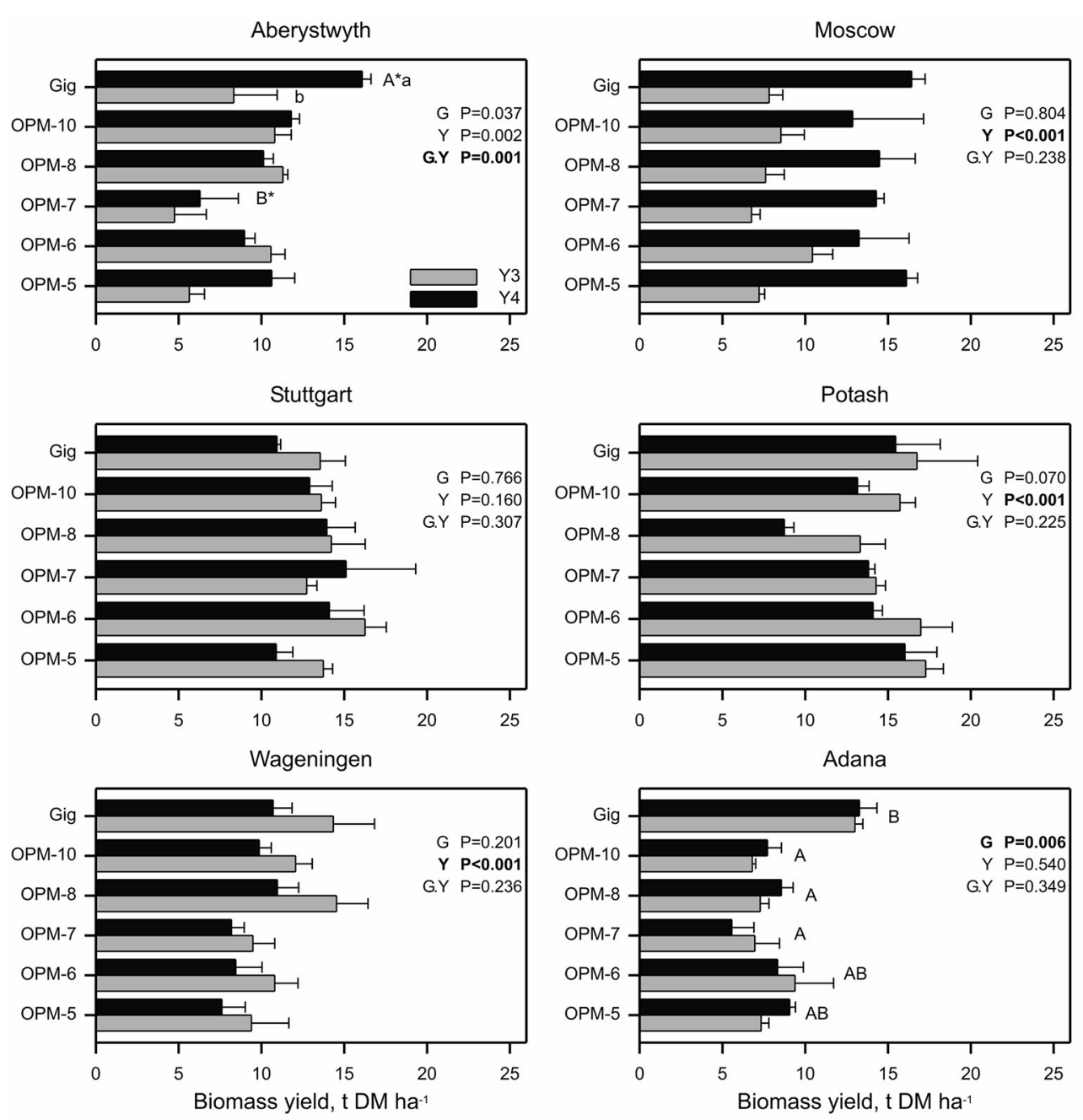

FIGURE 4 | Biomass yield of Miscanthus $\times$ giganteus and M. sinensis $\times$ M. sacchariflorus hybrids in 2014 (Y3) and 2015 (Y4) within six field trial locations. Error bars represent the standard error of the mean. Effects of genotype, year and interaction (genotype.year) are denoted by $G, Y$ and $G$.Y, respectively. At Adana, differing capital letters indicate genotype means differ $(p<0.05)$ based on bonferroni adjusted multiple comparisons. At Aberystwyth, differing capital letters $\left(A^{*}, B^{\star}\right)$ indicate genotype means within a year and differing lower case letters within a genotype indicate means differ between years $(p<0.05)$.

TABLE 4 | Season-end canopy height (cm) of 15 Miscanthus genotypes at six trial locations in 2014 (Y3) analyzed by REML using separate residual variances for each location.

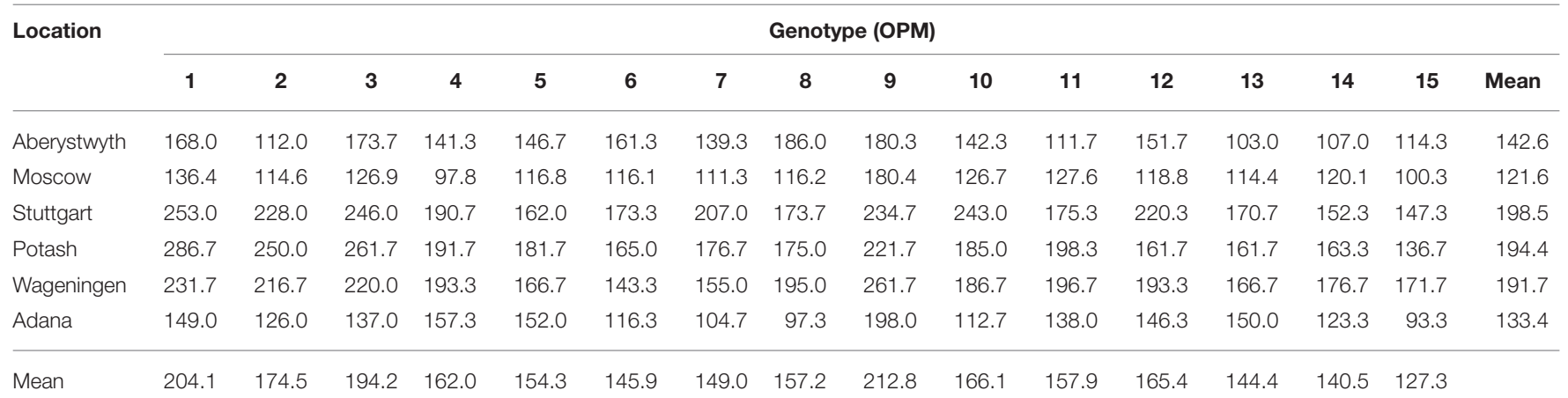

Statistical significance of effects of genotype $p<0.001$ (average s.e. 6.22), location $p<0.001$ (average s.e. 3.95) and interaction $p<0.001$ (average s.e. 13.68). 
TABLE 5 | Season-end stem count (stems plant ${ }^{-1}$ ) of 15 Miscanthus genotypes at six trial locations in 2014 (Y3) analyzed by REML using separate residual variances for each location.

\begin{tabular}{|c|c|c|c|c|c|c|c|c|c|c|c|c|c|c|c|c|}
\hline \multirow[t]{2}{*}{ Location } & \multicolumn{16}{|c|}{ Genotype (OPM) } \\
\hline & 1 & 2 & 3 & 4 & 5 & 6 & 7 & 8 & 9 & 10 & 11 & 12 & 13 & 14 & 15 & Mean \\
\hline Aberystwyth & 29.2 & 12.6 & 26.5 & 35.5 & 32.1 & 58.6 & 47.8 & 33.8 & 22.0 & 33.8 & 11.2 & 31.4 & 12.7 & 19.7 & 30.2 & 27.8 \\
\hline Moscow & 57.6 & 34.7 & 39.4 & 40.1 & 58.7 & 99.3 & 72.8 & 64.7 & 35.1 & 81.3 & 42.0 & 43.1 & 48.9 & 53.3 & 44.9 & 53.1 \\
\hline Stuttgart & 26.1 & 42.6 & 34.6 & 73.8 & 63.3 & 105.9 & 93.8 & 71.5 & 29.8 & 70.1 & 43.2 & 33.5 & 59.9 & 60.5 & 74.6 & 56.6 \\
\hline Potash & 31.4 & 34.9 & 38.0 & 35.7 & 45.3 & 40.7 & 77.6 & 48.3 & 23.9 & 73.2 & 21.3 & 13.5 & 21.4 & 30.8 & 19.9 & 35.1 \\
\hline Wageningen & 23.3 & 32.0 & 38.6 & 54.2 & 39.6 & 116.1 & 93.3 & 66.9 & 25.0 & 91.3 & 68.0 & 44.3 & 102.9 & 67.5 & 98.3 & 60.5 \\
\hline Adana & 49.5 & 52.5 & 54.1 & 42.7 & 39.6 & 43.5 & 49.6 & 36.5 & 41.2 & 70.9 & 54.7 & 55.8 & 43.2 & 36.6 & 32.0 & 46.4 \\
\hline Mean & 35.1 & 33.6 & 38.1 & 46.1 & 45.8 & 74.1 & 71.2 & 52.5 & 29.1 & 68.7 & 37.3 & 35.5 & 43.6 & 43.0 & 46.4 & \\
\hline
\end{tabular}

Statistical significance of effects of genotype $p<0.001$ (average s.e. 0.27; s.e. applies to means on square root scale), location $p<0.001$ (average s.e. 0.31 ) and interaction $p<0.001$ (average s.e. 0.66).

stem number $(r=0.21, p<0.001)$. Stem number and canopy height showed no association $(r=0.03, p=0.649)$. But there were also exceptions within the genotype, in particular, OPM-6, one of the highest yielding genotypes in years 3 and 4 , had a low canopy height but a high stem count.

\section{Phenotype Sensitivity to Location}

Both canopy height and stem number measured in year 3 showed significant differences in sensitivities across the six locations $(p=$ 0.007 and $p=0.01$, respectively).

In terms of canopy height genotypes OPM-2 and 1 were most sensitive, i.e., less stable across locations than overall mean sensitivity in the data set (Figure 5A), followed closely by OPM3 (all three belong to $M$. sacchariflorus species). The lowest sensitivities were observed for OPM-6 and 5, Sac $\times$ Sin hybrids, i.e., these genotypes had the most consistent canopy heights irrespective of the environment they were planted in.

For stem number, OPM-6, with the highest overall mean stem count, showed a higher than average sensitivity to location (tended to be less stable) than $M . \times$ giganteus and other genotypes with lower stem counts, e.g., OPM-1-4 $M$. sacchariflorus genotypes (Figure 5B). These tended to be the most stable. OPM-13 (M. sinensis) and OPM-15 (an openpollinated $\operatorname{Sac} \times \operatorname{Sin} \times \operatorname{Sin}$ hybrid), showed the least stable stem counts across locations, whereas for all the $M$. sacchariflorus genotypes rather low sensitivity values have been obtained. Among the hybrids OPM-5 and among the M. sinensis types OPM-12 showed lower sensitivities.

Biomass yield estimated in year 3 showed no significant difference in sensitivity across the six locations $(p=0.269)$. Overall, OPM-2 tended to be the least stable and OPM- 8 the most stable genotype (Figure 5C). The high-yielding Sac $\times$ Sin hybrids OPM- 6 and 7 showed higher than average yield sensitivity and this tended to be higher than that of $M . \times$ giganteus. Overall, all the M. sacchariflorus genotypes showed higher than average sensitivity, whereas most of the $M$. sinensis types tended to have lower than average sensitivity in yield to the locations studied. OPM-8, 13, and 15 had a similarly low yield sensitivity to $M . \times$ giganteus.

\section{DISCUSSION}

\section{Establishment and Survival}

In our experiment, the small plugs produced by in vitro tillering and seed were shipped to all the sites in boxes and were watered at planting. Several liters of water were applied to wet the soil in the immediate vicinity of the plug plant. This helps establish the hydraulic contact needed to prevent plug dehydration in the first 10 days while roots grow out of the plug into the soil. In most of the locations, transplanting success rates were close to $100 \%$. The exception was Aberystwyth, where the shallow soils (Supplementary Table 2) were too damp to create a fine tilth and the soil tilth was too "lumpy" to ensure a good hydraulic contact. Further, immediately after planting in Aberystwyth, there was a 2 week period of fine weather which dried the soil surface. This was followed by an exceptionally wet (double normal rainfall) weather conditions, cold (temperatures $<16^{\circ} \mathrm{C}$ ) and overcast in June-September (half normal radiation). This combination of conditions was highly unfavorable for Miscanthus establishment from delicate plugs, and resulted in high establishment plant losses. It was not our intention to make an in depth study of the agronomy of plant plug establishment as this was the task for the upscaling trials within the same OPTIMISC project (Lewandowski et al., 2016). The lessons learnt from the Aberystwyth site in the first year are nonetheless important for the subsequent agronomic trials on the establishment of Miscanthus from plugs in the cool wet climates and have been taken into account in the development of commercially relevant establishment protocols where safe reliable establishment of the crop is a pre-requisite to an industry based on Miscanthus biomass (Michal Mos and Chris Ashman, personal communication). In Aberystwyth, the lost plants were replaced with spare plants in June 2013. Weather conditions for growth in 2013 were more favorable than 2012, and no further plant losses occurred, allowing the $\mathrm{G} \times \mathrm{E}$ experiment to continue with measurements from the site in Aberystwyth.

It was expected that there would be differences in overwintering in the first winter following planting, particularly in the highly continental climates of Potash in Ukraine and Moscow in Russia. In Moscow, overwinter mortality was slightly 

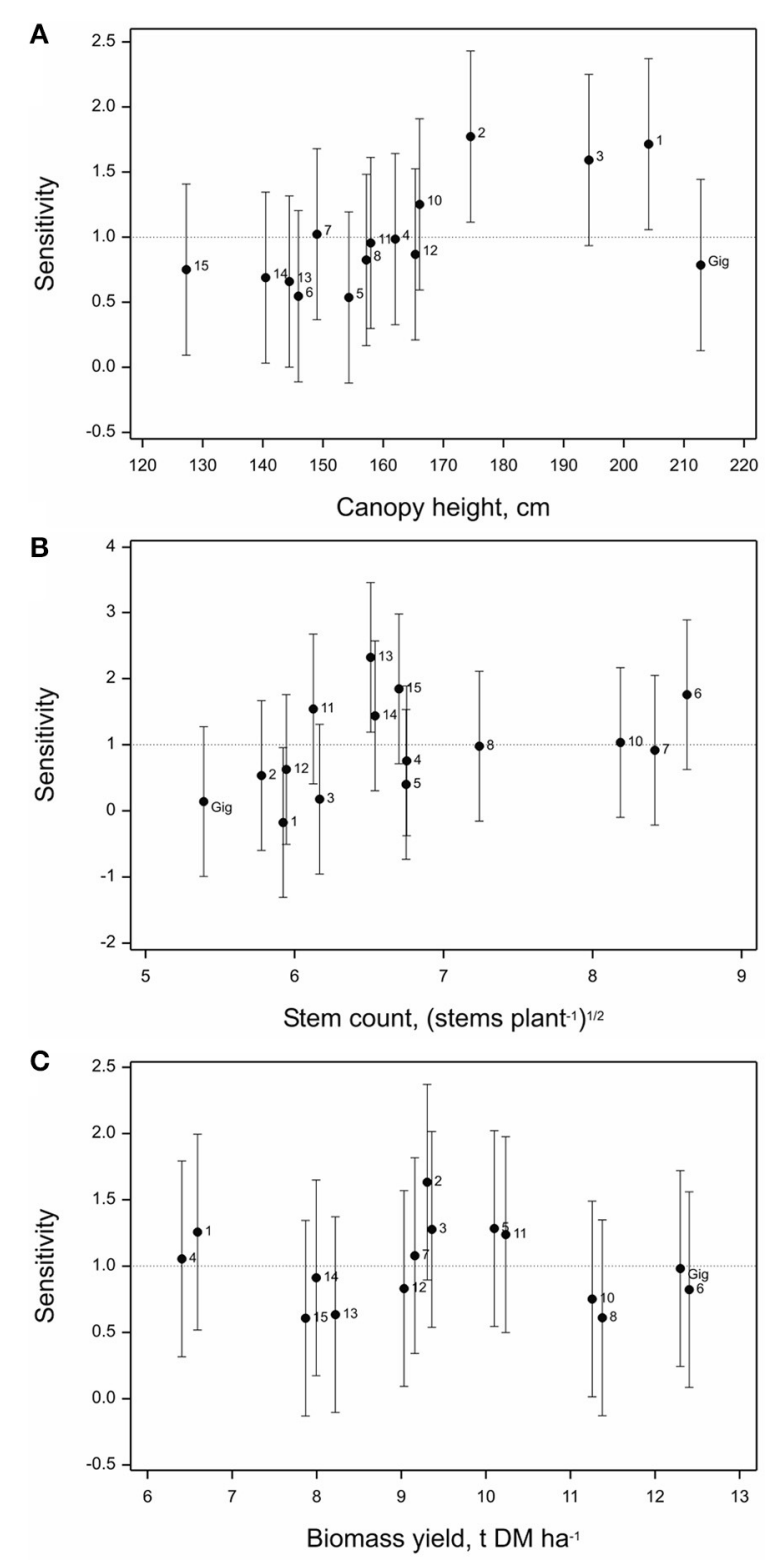

FIGURE 5 | Sensitivity of (A) canopy height, (B) stem count, and (C) biomass yield of 15 Miscanthus genotypes to location in 2014 (Y3) based on joint regression analysis (Finlay and Wilkinson, 1963). Labels 1-8, Gig, 9-15 denote OPM-1 to OPM-15, respectively, vertical bars denote $95 \%$ simultaneous confidence intervals for each sensitivity estimate and the horizontal dotted line denotes the overall mean sensitivity of all 15 genotypes.

higher than at most other locations (except Aberystwyth), which could be related to shorter growing season, spring frosts, and earlier low temperatures in autumn at this location. Earlier work indicated that there is a threshold (in terms of lethal temperature to kill $50 \%$ of the rhizomes, $\mathrm{LT}_{50}$ ) for overwinter freezing tolerance of the rhizomes of approximately $-3.5^{\circ} \mathrm{C}$ for $M$. sacchariflorus and $M . \times$ giganteus (Clifton-Brown and Lewandowski, 2000). Interestingly, a repeat of an earlier freezing experiment within OPTIMISC project by partners in
Belgium confirmed the $-3.5^{\circ} \mathrm{C} \mathrm{LT}_{50}$ (Fonteyne et al., 2016a,b). Unexpectedly, $M . \times$ giganteus survived in all sites, even in Moscow and Ukraine, where winter soil temperatures would normally have fallen below $-3.5^{\circ} \mathrm{C}$ sometime within the 4 year trial period (between 2012 and 2015). In fact soil temperatures did not fall below $-3.5^{\circ} \mathrm{C}$ at any of the sites, and consequently only low overwinter losses were recorded in Moscow and Potash. Some of the plant losses in Aberystwyth did occur overwinter, despite the fact that winter soil temperatures at $5 \mathrm{~cm}$ depth remained above freezing. The high establishment losses in Aberystwyth were more likely to be caused by the poor first season summer growing conditions which resulted in insufficient rhizome growth to overwinter, a problem seen in trials in Ireland over a decade ago (Clifton-Brown et al., 2015). In the OPTIMISC multi-location trial we did not measure the rhizome mass after the first growing season as we had done in an earlier trial (Clifton-Brown and Lewandowski, 2000) because this would have left unwanted gaps in the plots.

Adana (Turkey) provided the most exceptional environment in this experiment for early establishment. Here, without irrigation Miscanthus could not establish. However, with the application of irrigation amounts to almost completely cover potential evapotranspiration in the first year, the establishment rate was so rapid that many genotypes almost reached mature "ceiling" yields in a single growing season. In the Netherlands, where the soil has a light sandy texture, mature ceiling yields appear to have been reached by the end of the second year. In contrast, despite the favorable growing season temperatures and rainfall in Stuttgart, the mature yields were only attained by year 3. We believe this slower establishment is partly due to the heavy clay soil and highly variable soil depth $(40-100 \mathrm{~cm})$ across the site which impede rapid root and rhizome growth, In Ukraine, where the soil conditions were the best of all sites, and summer temperatures are favorable, yields increased consecutively until the third year but were reduced slightly in year 4 , due to significantly decreased summer rainfall. In contrast, yields in the Aberystwyth and Moscow sites rose slowly in the first and second years, but by the third and fourth year the difference in annual productivity between sites that established most quickly (Adana and Netherlands) had begun to narrow. It will require a further year or two to ascertain if indeed the ceiling yield was reached in fourth year in Aberystwyth and Moscow.

Interestingly, as the annual productive differences between the slower and faster establishing sites reduced with stand age, the yield differences between the sites over the crops lifespan of 12-20 years (Lesur et al., 2013) would be expected to narrow. We would expect significant differences in long-term yields of the different germplasm types would be detected if yield measurements could continue.

\section{Yield Performance and Environment}

The continental climate with warm summers, combined with nutrient-rich deep soils ensuring a good water supply throughout the growing season in Ukraine resulted in the highest ranked productivity of all the six sites over the first 4 years.

At Adana in Turkey, high yields could be achieved already in the first growing season and further yield increase was rather 
slow. A number of factors could contribute to high yields at this site. The trial in Adana was irrigated, evidently providing sufficient soil moisture content to allow successful and quick plant establishment. The Adana site had the highest PAR and degree-days ( $\mathrm{DD}_{\text {base } 0}$, base10 $)$ over the first growing season, and also the highest air and deep soil (over $2 \mathrm{~m}$ depth) temperatures among all the locations (Table 2; Supplementary Tables 2-6). The warm climate and long vegetation period seem to be advantageous for miscanthus yields at this site, when sufficient water supply was ensured. The literature sources report that $M$. $\times$ giganteus is providing higher yields in warmer, wetter areas with moderately heavy soils (Beale and Long, 1995; Lewandowski et al., 2000).

At two locations, in Aberystwyth and in Moscow, the yields were low in the first year after planting but continued gradually increasing over all the 4 years. The crop has possibly not yet achieved its peak yields at these two locations. As mentioned above, in Aberystwyth the weather in the first growing season directly after planting was most probably the key factor affecting the establishment and the first-year biomass yield. The total yield achieved at this location over 4 years was also the lowest among the trials. It is worth mentioning that the field trial at Aberystwyth was established on marginal, shallow soil poor on nutrients (Supplementary Tables 2, 3), on a former grassland, whereas the other trials were placed on arable or horticultural land.

The yields at Moscow site were comparable to the other sites and improved significantly in the years following establishment, reaching $16 \mathrm{t} \mathrm{DM} \mathrm{ha}{ }^{-1}$ for some genotypes (e.g., $M . \times$ giganteus) in year 4. Lower than expected overwinter mortality and good mature biomass yields at this site might be related to relatively mild winter soil temperatures in the years of assessment and deep snow cover preventing rhizome damage overwinter. Although air temperatures at this site (as well as in Potash in Ukraine) sometimes went lower than $-20^{\circ} \mathrm{C}$, soil temperature did not fall lower than $0.7^{\circ} \mathrm{C}$ at $20 \mathrm{~cm}$ depth in the first winter (Table 2). Deep soil and good plant available nitrogen supply at this site could also be advantageous for biomass production (Supplementary Tables 2, 3).

M. $\times$ giganteus gave its best yields at the sites with rich deep soil, such as Potash, or in a warm climate under sufficient irrigation, such as in Adana. M. sinensis genotypes on average showed their best yields in Adana, possibly profiting from a long vegetation period. Earlier, Robson et al. (2012) reported that $M$. sinensis genotypes may remain green for longer period than $M$. sacchariflorus genotypes.

Biomass yields were lower at Wageningen and Potash in the fourth growth season compared to the third. This could be a result of lower precipitation at these sites in the year 4, but also the other climate factors could play a role. Precipitation during the growing period is mentioned as the key factor for high miscanthus yields in the literature (Ercoli et al., 1999; Richter et al., 2008; Gauder et al., 2012). Some other factors, such as heat sum during the growing period, soil moisture and PAR, are also known to be important for biomass production (Gauder et al., 2012; Larsen et al., 2016). At Adana, the biomass yields dropped slightly in the last two growing seasons compared to the second which most probably was caused by the reduction in irrigation.

\section{Genetic Variation and Performance of the Genotypes across Sites}

Across all sites over 4 years, the rankings of the most productive genotypes/hybrids were quite similar and we found less environmental specificity than expected despite the wide climatic range of the six sites. Unexpectedly, $M . \times$ giganteus survived in all sites and by the third and fourth years was amongst the highest yielding types and is a key "generic high performing genotype" with wide climatic adaptability.

The interspecies hybrid group produced more biomass than both the $M$. sacchariflorus and $M$. sinensis groups. This confirms the importance of interspecies crosses to achieve the highest yields. Overall, $M . \times$ giganteus was the highest yielding clone and OPM-6 hybrid came a close second. The low environmental specificity was a surprising result, since we expected that there would be a greater requirement for matching germplasm types to cope with environmental extremes of overwinter cold in Ukraine and Moscow and drought and heat in Adana. The relatively early senescing clone, OPM-10, was a consistent "performer" across all sites, but never the highest yielding type in any location. OPM-10's environmental resilience is noteworthy because resilience is key to production and survival in marginal land types where extremes of drought, sometimes combined with low temperatures in and out of the growing season, limit the production of food crops.

When we set up the multi-location trial in 2012, we expected the warm summers in Adana would cause similar stunting effects to those observed in Texas (Charlie Rodgers, personal communication). In fact $M . \times$ giganteus performed much better than expected. From this we conclude that Miscanthus $\times$ giganteus is still within its range of thermal adaptation in Adana and that the growing season water availability is the main constraint for production in southern Mediterranean climate, rather than heat stress. Interestingly, with reduced irrigation levels in the third and fourth growing seasons in Adana, the water saving strategies of the $M$. sinensis types detected in earlier experiments (Clifton-Brown et al., 2002), were confirmed by the significant jump in yield rank (in particular OPM-13). As irrigation water is expensive, maximizing the biomass production through improved water use efficiency is very important and a subject of intense research in several interrelated research projects, of which EU FP7's WATBIO (Taylor et al., 2016) is one of the most comprehensive including genomics for breeding.

The relatively low environment sensitivity in many selections, have both advantages and disadvantages for further breeding. A key advantage is that leading selections made in plot trials in "central" locations such as Braunschweig in Germany (with cold continental winters, warm summers with regular water deficits) have wide relevance for the selection of novel germplasm for much of Europe.

\section{Yield Traits}

Across all sites and all genotypes in 2014, there were significant positive correlations between harvested yield and autumn canopy 
height and stem number. For this set of germplasm, canopy height ( $r=0.55$ ) appeared to be more predictive for the biomass yield than stem number $(r=0.21)$. Although, these correlations were statistically significant they explained only a minor part of the observed variation in yield. In particular, OPM-6 hybrid, one of the highest yielding genotypes, had a low canopy height but a high stem count compared to the other genotypes.

A number of studies have reported correlations between yield and various morphological and physiological parameters in miscanthus (Jeżowski, 2008; Gauder et al., 2012; Robson et al., 2013; Maddison et al., 2017). Several earlier studies showed that tillering is among the most important traits influencing biomass yield (Jeżowski, 2008; Nie et al., 2016). Our results have only shown a weak association between the stem number and yield for the set of germplasm evaluated. The higher stem numbers are often associated with thinner stems (Robson et al., 2013). In the same field trial we found that germplasm types with higher stem counts have lower moisture contents at harvest $(r=-0.43$, $p<0.001$; data not shown in this manuscript). These thinner stemmed types are easier to cut and bale at harvest than those with thicker stems (Hastings et al., 2017). They however have the disadvantage that leaf shares are higher than in the tallest genotypes (such as OPM-1 and 9), which can increase the ash content (Iqbal et al., 2017). Here, it is worth mentioning that since only stems reaching at least $60 \%$ of the canopy height were counted, this measurement may underestimate the total shoot number for the $M$. sinensis genotypes (which tend to produce multiple short stems).

To date morphological characterization has largely been carried out in "spaced plant" breeding nurseries. While spaced plant nurseries are needed to handle the large numbers of genotypes to be screened in breeding, yield may or may not correlate to in plot yield performance where the individual plants are tested in "competitive" plant stands with full canopy closure. Planting densities have a very important role to play in yield determination. In our multi-location trial we decided to standardize the planting density at two plants $\mathrm{m}^{-2}$ for all germplasm types based on prior experience (Clifton-Brown et al., 2001). There are many complex interactions between planting density and the germplasm morphological characteristics such as height, shoot density and growing environment. Since such trials are resource intensive these experiments should only be attempted on a very few highly promising novel hybrids.

The new data from this multi-location trial confounds our efforts to identify simple ideotypes for high yield. Both short and tall morphotypes can be effective strategies. This points us back to the importance of work on whole season photosynthetic efficiency where we know interspecies hybrids such as $M . \times$ giganteus have proved outstanding at low temperatures (Beale and Long, 1995; Davey et al., 2017). This is further complicated by environmental plasticity. For example under extremely hot climate, the morphology of $M . \times$ giganteus, which expresses a dominant phenotype associated with its tall $M$. sacchariflorus parent when grown in temperate climates (with a canopy height over $3 \mathrm{~m}$ ), changes to a more $M$. sinensis phenotype with a multitude of short thin stems and a canopy height of about $1 \mathrm{~m}$.

\section{CONCLUSIONS}

Performance of the 15 genotypes of miscanthus has been assessed across a wide range of environments in the European countries, Russia and Turkey. A number of genotypes, in particular interspecies hybrids of $M$. sinensis and $M$. sacchariflorus showed good yield potential to be used in parallel or as a replacement to $M . \times$ giganteus standard clone. In particular, Sac $\times$ Sin hybrids were high-yielding. Two of these, OPM-6 and 7 provided similar to $M . \times$ giganteus biomass yields at most locations.

Environment-sensitive genotypes, which showed high yields but low yield stability across geographic sites, such as e.g., OPM2 (M. sacchariflorus) can be recommended for use in particular locations, where they are the most productive. Whereas, the genotypes providing stable yields in different environments, such as OPM-8 or 13 , can be valuable for breeding programs of miscanthus. Interestingly, $M . \times$ giganteus produced high biomass yields at multiple sites and showed a high yield stability in the Finlay Wilkinson analysis. M. sacchariflorus germplasm types showed high yields but the yields were more vulnerable to the environmental conditions and varied among the locations. The M. sinensis genotypes had overall lower yields (with some exceptions) but the yields were more stable across the locations.

This multi-location trial showed that the range of miscanthus cultivation can be extended into the Eastern areas, also for the standard clone $M . \times$ giganteus which showed good overwintering in this study. Climate changes are reducing the severity of winters, and it appears to be safe to plant Miscanthus further eastwards than earlier predicted, e.g., Hastings et al. (2009a,b).

\section{AUTHOR CONTRIBUTIONS}

OK, JC, IL designed and planned the experiments; OK, CN, TV, MÖ, IT, HS performed the experiments; OK, RS analyzed the data; OK drafted the manuscript; CN, RS, IL, JC, AH, LT critically revised the manuscript draft; all the authors revised and approved the final version to be published.

\section{FUNDING}

The OPTIMISC project received funding from the European Union Seventh Framework Programme (FP7/2007-2013) under grant agreement No. 289159.

\section{ACKNOWLEDGMENTS}

The authors are grateful to Heike Meyer (Braunschweig) for the production of the plug plants by in vitro cloning for all the sites. We would also like to thank the staff of the research station Ihinger Hof, especially Thomas Truckses, for maintaining and managing the field trial at the Stuttgart site.

\section{SUPPLEMENTARY MATERIAL}

The Supplementary Material for this article can be found online at: http://journal.frontiersin.org/article/10.3389/fpls.2017. 00563/full\#supplementary-material 


\section{REFERENCES}

Allen, B., Kretschmer, B., Baldock, D., Menadue, H., Nanni, S., and Tucker, G. (2014). Space for Energy Crops - Assessing the Potential Contribution to Europe's Energy Future. Report produced for BirdLife Europe, European Environmental Bureau and Transport \& Environment. Institute for European Environmental Policy (IEEP), London. Available online at: http://www.eeb.org/EEB/?LinkServID $=$ F6E6DA60-5056-B741-DBD250D05D441B53

Anderson, N. O., Gomez, N., and Galatowitsch, S. M. (2006). A noninvasive crop ideotype to reduce invasive potential. Euphytica 148, 185-202. doi: 10.1007/s10681-006-5936-6

Beale, C. V., and Long, S. P. (1995). Can perennial C4 grasses attain high efficiencies of radiant energy conversion in cool climates? Plant Cell Environ. 18, 641-650. doi: 10.1111/j.1365-3040.1995.tb00565.x

Clifton-Brown, J. C., Lewandowski, I., Andersson, B., Basch, G., Christian, D. G., Kjeldsen, J. B., et al. (2001). Performance of 15 Miscanthus genotypes at five sites in Europe. Agron. J. 93, 1013-1019. doi: 10.2134/agronj2001.9351013x

Clifton-Brown, J. C., Lewandowski, I., Bangerth, F., and Jones, M. B. (2002). Comparative responses to water stress in stay-green, rapid- and slow senescing genotypes of the biomass crop, Miscanthus. New Phytol. 154, 335-345. doi: 10.1046/j.1469-8137.2002.00381.x

Clifton-Brown, J. C., Renvoize, S. A., Chiang, Y.-C., Ibaragi, Y., Flavell, R., Greef, J. M., et al. (2011). "Developing Miscanthus for Bioenergy," in Energy Crops, eds N. G. Halford and A. Karp (London: Royal Society of Chemistry), 301-321.

Clifton-Brown, J., and Lewandowski, I. (2000). Overwintering problems of newly established Miscanthus plantations can be overcome by identifying genotypes with improved rhizome cold tolerance. New Phytol. 148, 287-294. doi: 10.1046/j.1469-8137.2000.00764.x

Clifton-Brown, J., Hastings, A., Mos, M., McCalmont, J. P., Ashman, C., AwtyCarroll, D., et al. (2016). Progress in upscaling Miscanthus biomass production for the European bio-economy with seed-based hybrids. GCB Bioenergy 9, 6-17. doi: 10.1111/gcbb.12357

Clifton-Brown, J., Neilson, B., Lewandowski, I., and Jones, M. B. (2000). The modelled productivity of Miscanthus $\times$ giganteus (GREEF et DEU) in Ireland. Ind. Crops Prod. 12, 97-109. doi: 10.1016/S0926-6690(00)00042-X

Clifton-Brown, J., Robson, P., Sanderson, R., Hastings, A., Valentine, J., and Donnison, I. (2011). Thermal requirements for seed germination in Miscanthus compared with switchgrass (Panicum virgatum), reed canary grass (Phalaris arundinaceae), maize (Zea mays) and perennial ryegrass (Lolium perenne). GCB Bioenergy 3, 375-386. doi: 10.1111/j.1757-1707.2011.01094.x

Clifton-Brown, J., Schwarz, K. U., and Hastings, A. (2015). History of the development of miscanthus as a bioenergy crop: from small beginnings to potential realisation. Biol. Environ. Proc. R. Ir. Acad. 115B, 45-57. doi: 10.3318/bioe. 2015.05

Davey, C. J., Jones, L. E., Laurence, E. J., Squance, M., Purdy, S., Maddison, A., et al. (2017). Radiation capture and conversion efficiencies of Miscanthus sacchariflorus, M. sinensis and their naturally occurring hybrid M. $\times$ giganteus. GCB Bioenergy 9, 385-399. doi: 10.1111/gcbb.12331

Dohleman, F. G., and Long, S. P. (2009). More productive than maize in the Midwest: how does Miscanthus do it? Plant Physiol. 150, 2104-2115. doi: 10.1104/pp.109.139162

Ehmann, A., Bach, I. M., Laopeamthong, S., Bilbao, J., and Lewandowski, I. (2017). Can phosphate salts recovered from manure replace conventional phosphate fertilizer? Agriculture 7:1. doi: 10.3390/agriculture7010001

Ercoli, L., Mariotti, M., Masoni, A., and Bonari, E. (1999). Effect of irrigation and nitrogen fertilization on biomass yield and efficiency of energy use in crop production of Miscanthus. Field Crops Res. 63, 3-11. doi: 10.1016/S0378-4290(99)00022-2

Finlay, K. W., and Wilkinson, G. N. (1963). The analysis of adaptation in a plantbreeding programme. Aust. J. Agric. Res. 14, 742-754. doi: 10.1071/AR9630742

Fonteyne, S., Lootens, P., Muylle, H., Van den Ende, W., De Swaef, T., Reheul, D., et al. (2016b). Chilling tolerance and early vigour related characteristics evaluated in two Miscanthus genotypes. Photosynthetica 54, 295-306. doi: 10.1007/s11099-016-0193-y

Fonteyne, S., Muylle, H., De Swaef, T., Reheul, D., Roldán-Ruiz, I., and Lootens, P. (2016a). How low can you go? Rhizome and shoot frost tolerance in miscanthus germplasm. Ind. Crops Prod. 89, 323-331. doi: 10.1016/j.indcrop.2016 05.031

Gauder, M., Graeff-Hönninger, S., Lewandowski, I., and Claupein, W. (2012). Long-term yield and performance of 15 different Miscanthus genotypes in southwest Germany. Ann. Appl. Biol. 160, 126-136. doi: 10.1111/j.1744-7348.2011.00526.x

Greef, J. M., and Deuter, M. (1993). Syntaxonomy of Miscanthus $\times$ giganteus GREEF et DEU. Angew. Bot. 67, 87-90.

Hastings, A., Clifton-Brown, J., Wattenbach, M., Mitchell, C. P., Stampfl, P., and Smith, P. (2009a). Future energy potential of Miscanthus in Europe. GCB Bioenergy 1, 180-196. doi: 10.1111/j.1757-1707.2009.01012.x

Hastings, A., Clifton-Brown, J., Wattenbach, M., Mitchell, C., and Smith, P. (2009b). The development of MISCANFOR, a new Miscanthus crop growth model: towards more robust yield predictions under different climatic and soil conditions. GCB Bioenergy 1, 154-170. doi: 10.1111/j.1757-1707.2009.01007.x

Hastings, A., Mos, M., Yesufu, J. A., McCalmont, J., Ashman, C., Nunn, C., et al. (2017). Economic and environmental assessment of seed and rhizome propagated Miscanthus in the UK. Front. Plant Sci.

Hodkinson, T. R., and Renvoize, S. (2001). Nomenclature of Miscanthus $\times$ giganteus (Poaceae). Kew Bull 56, 759-760. doi: 10.2307/4117709

Hodkinson, T. R., Petrunenko, E., Klaas, M., Münnich, C., Barth, S., Shekhovtsov, S. V., et al. (2016). "New breeding collections of Miscanthus sinensis, M. sacchariflorus and hybrids from Primorsky Krai, Far Eastern Russia," in Perennial Biomass Crops for a Resource-Constrained World, eds S. Barth, D. Murphy-Bokern, O. Kalinina, G. Taylor, and M. Jones (Cham: Springer International Publishing), 105-118. doi: 10.1007/978-3-319-44530-4

Iqbal, Y., and Lewandowski, I. (2014). Inter-annual variation in biomass combustion quality traits over five years in fifteen Miscanthus genotypes in south Germany. Fuel Process Technol. 121, 47-55. doi: 10.1016/j.fuproc.2014.01.003

Iqbal, Y., Nunn, C., Hastings, A., Kalinina, O., Khokhlov, N., Kiesel, A., et al. (2017). Harvest time optimisation of miscanthus genotypes for different biomass end uses. Front. Plant Sci. (Accepted with minor revision).

Jensen, E., Farrar, K., Thomas-Jones, S., Hastings, A., Donnison, I., and CliftonBrown, J. (2011). Characterization of flowering time diversity in Miscanthus species. GCB Bioenergy 3, 387-400. doi: 10.1111/j.1757-1707.2011.01097.x

Jensen, E., Robson, P., Norris, J., Cookson, A., Farrar, K., Donnison, I., et al. (2013). Flowering induction in the bioenergy grass Miscanthus sacchariflorus is a quantitative short-day response, whilst delayed flowering under long days increases biomass accumulation. J. Exp. Bot. 64, 541-552. doi: $10.1093 /$ jxb/ers346

Jeżowski, S. (2008). Yield traits of six clones of Miscanthus in the first 3 years following planting in Poland. Ind. Crops Prod. 27.1, 65-68. doi: 10.1016/j.indcrop.2007.07.013

Larsen, S., Jaiswal, D., Bentsen, N. S., Wang, D., and Long, S. P. (2016). Comparing predicted yield and yield stability of willow and Miscanthus across Denmark. GCB Bioenergy 8, 1061-1070. doi: 10.1111/gcbb.12318

Lesur, C., Jeuffroy, M. H., Makowski, D., Riche, A. B., Shield, I., Yates, N., et al. (2013). Modeling long-term yield trends of Miscanthus $\times$ giganteus using experimental data from across Europe. Field Crops Res. 149, 252-260. doi: 10.1016/j.fcr.2013.05.004

Lewandowski, I., Clifton-Brown, J. C., Scurlock, J. M. O., and Huisman, W. (2000). Miscanthus: European experience with a novel energy crop. Biomass Bioenergy 19, 209-227. doi: 10.1016/S0961-9534(00)00032-5

Lewandowski, I., Clifton-Brown, J., Trindade, L. M., van der Linden, G. C., Schwarz, K.-U., Müller-Sämann, K., et al. (2016). Progress on optimizing Miscanthus biomass production for the European bioeconomy: results of the EU FP7 project OPTIMISC. Front. Plant Sci. 7:1620. doi: $10.3389 /$ fpls.2016.01620

Maddison, A. L., Camargo-Rodriguez, A., Scott, I. M., Jones, C. M., Elias, D. M. O., Hawkins, S., et al. (2017). Predicting future biomass yield in Miscanthus using the carbohydrate metabolic profile as a biomarker. GCB Bioenergy doi: $10.1111 /$ gcbb. 12418

McCalmont, J. P., Hastings, A., McNamara, N. P., Richter, G. M., Robson, P., Donnison, I. S., et al. (2015). Environmental costs and benefits of growing Miscanthus for bioenergy in the UK. GCB Bioenergy 9, 489-507. doi: 10.1111/gcbb.12294 
Nie, G., Huang, L., Zhang, X., Taylor, M., Jiang, Y., Yu, X., et al. (2016). Marker-trait association for biomass yield of potential bio-fuel feedstock Miscanthus sinensis from Southwest China. Front. Plant Sci. 7:802. doi: 10.3389/fpls.2016.00802

Payne, R. W., Murray, D. A., Harding, S. A., Baird, D. B., and Soutar, D. M. (2015). Introduction to Genstat ${ }^{\circledR}$ for Windows ${ }^{T M}$, 18th Edn. Hemel Hempstead: VSN International.

Richter, G. M., Riche, A. B., Dailey, A. G., Gezan, S. A., and Powlson, D. S. (2008). Is UK biofuel supply from Miscanthus water-limited? Soil Use Manag. 24, 235-245. doi: 10.1111/j.1475-2743.2008.00156.x

Robson, P., Jensen, E., Hawkins, S., White, S. R., Kenobi, K., Clifton-Brown, J., et al. (2013). Accelerating the domestication of a bioenergy crop: identifying and modelling morphological targets for sustainable yield increase in Miscanthus. J. Exp. Bot. 64, 4143-4155. doi: 10.1093/jxb/ert225

Robson, P., Mos, M., Clifton-Brown, J., and Donnison, I. (2012). Phenotypic variation in senescence in Miscanthus: towards optimising biomass quality and quantity. Bioenergy Res. 5, 95-105. doi: 10.1007/s12155-0119118-6

Taylor, G., Allwright, M. R., Smith, H. K., Polle, A., Wildhagen, H., Hertzberg, M., et al. (2016). "Bioenergy trees: genetic and genomic strategies to improve yield," in Perennial Biomass Crops for a Resource-Constrained World, eds S. Barth, D. Murphy-Bokern, O. Kalinina, G. Taylor, and M. Jones (Cham: Springer International Publishing), 167-190.

Xue, S., Kalinina, O., and Lewandowski, I. (2015). Present and future options for Miscanthus propagation and establishment. Renew. Sustain. Energy Rev. 49, 1233-1246. doi: 10.1016/j.rser.2015.04.168

Conflict of Interest Statement: The authors declare that the research was conducted in the absence of any commercial or financial relationships that could be construed as a potential conflict of interest.

Copyright (c) 2017 Kalinina, Nunn, Sanderson, Hastings, van der Weijde, Özgüven, Tarakanov, Schüle, Trindade, Dolstra, Schwarz, Iqbal, Kiesel, Mos, Lewandowsk and Clifton-Brown. This is an open-access article distributed under the terms of the Creative Commons Attribution License (CC BY). The use, distribution or reproduction in other forums is permitted, provided the original author (s) or licensor are credited and that the original publication in this journal is cited, in accordance with accepted academic practice. No use, distribution or reproduction is permitted which does not comply with these terms. 